\title{
The Evaluation Of The Leadership Role Of School Principal
}

\author{
Pedro da Costa Miranda; Ade Iriani
}

\author{
Masters Study Program of Educational Administration \\ Faculty of Teacher Training and Education Satya Wacana Christian University \\ Diponegoro Street 52-60 Salatiga Central Java Indonesia \\ mirandacostap74@gmail.com, ade.iriani@uksw.edu
}

Article received: January 2021; revised: April 2021 ; accepted : April 2021

DOI : $10.17977 /$ um025v5i22021p73

\begin{abstract}
This study aims to evaluate the leadership role of school principals in Ensino Secundario Geral Cristal. This type of research is descriptive qualitative by using the Discrepancy evaluation model. Data collection techniques using interviews, observation, and documentation. The results showed that (1) the design component has a category that shows the role of principal leadership using management with good planning to make initial programs under the mission and vision in the learning process; (2) the installation component shows the leadership role of the principal in complementing the facilities and infrastructure as school facilities; (3) the process component shows that teaching and learning activities are following the curriculum and the role of the principal in strengthening teacher performance in learning; (4) the product component shows that the school has produced competent students.
\end{abstract}

Keywords: The Leadership; Principal; Discrepancy

Timor-Leste is a country on the Asian continent, which only became independent on 20 May 2002. Since the restoration of independence, great efforts have been made to improve the education system, and great progress has been made, especially in expanding access to education. These efforts are mandated by law. the Constitution of the Democratic Republic of Timor-Leste, Article 59 on education and culture (2002) is stated:

1. The State recognizes and guarantees the rights of citizens to education and culture, it is obliged to encourage the establishment of a universal, compulsory and within the limits of the state's capacity for basic education, free of charge, based on law.

2. All citizens have the right to equal opportunities for learning and professional education.

3. The State recognizes and supervises private and cooperative education.

4. The State has to guarantee to all citizens access to a higher level of education, scientific research, and works of art in accordance with their respective abilities,

5. All citizens have the right to develop cultural works and creations and are obliged to protect, maintain and preserve cultural heritage.

In Timor-Leste, the progress of educational institutions also depends on the figure of someone who leads the institution or organization, namely the school principal who is the highest leader and plays the role of the highest leader in both the Early Childhood Education (Pre-Eskolar), Ensino Elementary (Elementary School), Ensino Pre-Secundaria (Junior High School), Ensino Secundaria (High School), Ensino Tecnico Vocational (Vocational High School).

The progress and retreat of an educational institution depend on the management carried out by the leadership as their superiors. Therefore, good school leadership is a demand for the needs of the community hopefully that schools as education providers could answer the challenges of changing developments in socio-political, economic, and cultural policies in a country. 
From Carpente's research (2015), it shows that various efforts have been made by school principals in developing school culture, by these efforts include strengthening the basic values of habits at school, and providing guidance to school members, then making other routine events, providing assessment and appreciation, being responsive to external and internal problems, and carrying out coordination and control.

Nadur (2011), in his research, concluded that the school principal's transformational leadership is a leadership style that prioritizes providing opportunities that encourage all elements or elements of the school (teachers, students, employees/staff, parents of students, the surrounding community and others) to work hard based on the system, high values (values system) so that all elements in the school are willing to participate optimally in achieving the school's vision.

Maisyaroh (2018) said that the assessment of the role of the school principal is essentially a process of measuring the level or degree of implementation of a person's task or job and the school principal as a learning leader. That which is more complete and procedural, the school principal's performance assessment is the process of collecting, processing, analyzing, and interpreting data about the quality of the implementation of the school principal's work as learning leaders in the quality level that has been achieved from a certain predetermined goal, namely learning achievement and student growth. Carpente (2015) coined that school leaders must provide supportive leadership and shared structures for teachers to ensure a positive school culture and an effective professional learning community that has an impact on school improvement.

Based on the conclusions mentioned above, Carpente discussed the development of school culture and the consolidation of basic values in schools and supportive leadership, Nadur and Maisyaroh discussed school culture, leadership characteristics towards subordinates in school institutions, and also about transformational leadership and systems in assessment in school and participatory optimally for the achievement of the vision and mission of educators.

Ensino Secundaria Geral Cristal Balide Dili Timor-Leste has been established since the TimorLeste is still part of Indonesia. After the independence day, the name of the private school did not change, continuing its mission and vision as a school like other private schools operating following its statutes. Initial data obtained in the field through observation and distance interviews with one of the teachers at the school as a resource showed some problems. The first thing is the problem in the field of management, especially from the aspect of school principal leadership such as the role that requires the maximum to lead the school, it is necessary to equalize the perceptions of staff, rarely provide good motivation to teachers. Second, in terms of the number of students, from year to year, this school accepts the number of new students who are not permanent. In 2017 with a total of 472 students, in 2018 the number of students was 550 students, and in 2019 the number of students was 442 students, so the number of students fluctuated. Third, the quality of service, both from the aspect of Human Resources (HR): teachers, employees, technicians, low levels of and facilities and infrastructure: laboratories, libraries, public facilities, buildings/buildings, inadequate comfort and security, and student creativity programs. which is not optimal yet.

This might be the role of the school principal as an educational leader who leads the institution in the Ensino Secundaria Geral has not been optimal. Therefore, the researchers are interested in evaluating the role of school principal leadership on teacher performance in Ensino Secundari Geral Cristal TimorLeste. This research is evaluation research using the Discrepancy model which will only discuss (4) the four components of (5) the five components. So hopefully that the leadership of the principal in Ensino Sekundario Geral Cristal could find out the performance of teachers as implementing the school principal policies in order to realize the vision and mission of the school that has been stuck for 20 years.

\section{METHODS}

This type of research is a type of evaluative research with a qualitative approach. The qualitative approach is a very relevant approach to researching phenomena that occur in society 
because observations are directed at the background and the individual holistically and see them as part of a whole, not based on variables or hypotheses so that through a qualitative approach, research can obtain information in more detail about the conditions, situations, and events that occurred. The evaluation model used in this research is the discrepancy evaluation model.

This discrepancy model is used to find out whether the leadership role of the school principal in Ensino Secundario Geral Cristal has worked well in achieving the vision and mission that has been achieved or not. In this study, the researcher used a qualitative approach because the researcher would take a picture of all the activities in the field and the data collected through interviews with respondents, both school principals, curriculum staff, teachers, and related parties (stakeholders), observations included activities carried out by school principals, curriculum staff, teachers, and related parties, and study documentation in the form of a real picture that occurs in the field in accordance with the teaching and learning process in schools.

\section{RESULTS AND DISCUSSION}

From Ensino Secundario Geral Cristal (ESGC), Staff, (2020), the Timor-Leste Cristal Foundation (Fundasaun Cristal) was founded in 1984, this foundation was formed as an initiative of young intellectuals to participate in the process of developing youth education at that time. There are 10 (ten) founders of the foundation including Francisco A. Dos Santos, Eduardo Tilman, Agustinho dos Santos Gonçalves, Anselmo da Conceição, Jacinto de Oliveira, Filipe Garcia, Tito dos S. Baptista, no Miquel dos Santos Esteves. All funding comes from the founders and partly from donors. The location of the teaching and learning process in 1984 had to move three times because there were not yet adequate places, in 1985 the Cristal foundation had a permanent foundation office and a school office which is now occupied to carry out the teaching and learning process. At that time, civil servants were prioritized for the first batch of students. The school fee at that time was IDR 5,000. The change of school principals during the Indonesian era occurred four (4) times. The first school principal was named Filipe Garcia and the deputy was Mrs. Merry Cristina.

After the transition in 2000 to Timor-Leste independence day, the Cristal Foundation and its schools had to return to zero. At that time the foundation entrusted Mr. Rafael Sávio, S.Pd.MM was the first school principal during the independence era until now. In 2001 Ensino Secundario Geral Cristal was registered with the NGO / FORUM under no. 68 RDTL regulations as the container for all schools in Timor-Leste. In 2009 it was registered with the Ministry of Education in Timor-Leste. Notariado, (2009) Rejistu Notariado Ministerio Justisa RDTL ho numeru 8116/2009.

\section{The Condition of Students, Educators and Education Personnel, Facilities and Infra- structure}

In the last 3 years, the number of students in the Ensino Secundaria Geral Cristal student has fluctuated. From the data collected from schools, the number of students for the last 3 years is shown in Tables 1 and 2 .

\begin{tabular}{ccc}
\hline No & Year & Number of Students \\
\hline 1 & 2017 & 472 students \\
2 & 2018 & 550 students \\
3 & 2019 & 442 students \\
\hline
\end{tabular}

Tabel 1. student data for the last 3 years at Ensino Secundario Geral Cristal 


\begin{tabular}{cllcc}
\hline No & Position & \multicolumn{1}{c}{ Status } & Graduates & Total \\
\hline 1 & School principal & Contract from the Cristal Foundation \\
2 & Deputy of school & Master Degree & 1 person \\
& & Contract from the Cristal Foundation & Bachelor Degree & 4 people \\
3 & Teacher & Government employees & $\begin{array}{c}\text { Associate Degree, } \\
\text { Bachelor Degree }\end{array}$ & 9 people \\
& & Contracts from the Government & $\begin{array}{c}\text { Associate Degree, } \\
\text { Bachelor Degree }\end{array}$ & 16 people \\
& Teacher & Contract from the Cristal Foundation & Bachelor Degree & 21 people \\
\hline
\end{tabular}

Table 2 Data for civil servant teachers and contract teachers

\section{The Evaluation of Leadership Program Design at Ensino Secundario Geral Cristal Dili, Timor-Leste}

The leadership of the school principal includes the background, goals, and design of the school principal's leadership program in Ensino Secundario Geral Cristal). According to Sultoni, Bafadal, and Sudharta (2018), the school principal has good behavior according to the school principal's personality competency indicator, that leadership is a determining factor in an institution, the success or failure of the company in achieving a goal is influenced by the way of a leader.

The school principal is one of the factors that can encourage the school to realize the vision, mission, goals, and objectives of the school through programs which mean that the school principal is required to have adequate management and leadership skills in order to take the initiative to improve the quality of school education. Saputro (2018) said that implementing character education through three stages, namely the planning stage, the implementation stage, and the monitoring and evaluation stage. (Hasibuan, 2018) according to him, leadership is a way for a leader to influence the behavior of subordinates, so that they are willing to work together and can work productively to achieve company goals. Sunarto (2019) argued that the school principal is quite successful in improving the performance of educators and education management needs to be democratic, school principal leadership is the school principal's way or effort in influencing (influencing), encouraging, guiding, directing, and mobilizing teachers, students, parents and students, and other related parties to work/participate in achieving the stated goals.

\section{The Discussion on the Components of the Leadership Program Installation at Ensino Secundario Geral Cristal Dili, Timor-Leste}

Referring to the results of the research on the component of the school principal's leadership installation at Ensino Secundario Geral Cristal, it includes program implementation strategies, facilities and infrastructure, and human resources to support the program with the curriculum. The program implementation strategy includes how the school plans the program so that it can run well. Program planning contains various kinds of activities to be launched, implementation time, human resources who carry out it, and what infrastructure is needed when running the program.

The leadership of the school principal at Ensino Secundario Geral Cristal is also an educator, (s)he has to carry out planning, management, and evaluation activities for learning in the school being led. Siregar (2017) mentioned that the learning process can be carried out effectively when schools are able to utilize and manage their resources such as educators (school teachers), educational facilities, and infrastructure and curriculum.

From leadership in an educational institution, it can be seen from all aspects, so Maisyaroh (2018) said that the assessment of the role of the school principal is essentially a measurement process of the level or degree of carrying out one's duties or work, and the principal as a learning leader. That which is more complete and procedural, the assessment of the school principal's performance is the process 
of collecting, processing, analyzing, and interpreting data about the quality of the implementation of the principal's work as learning leaders in the level of quality that has been achieved from a certain predetermined goal.

\section{The Discussion of Process Components in School Principal Leadership at Ensino Secundario Geral Cristal Dili, Timor-Leste}

Referring to the results of research on Process components in school principal leadership at Ensino Secundario Geral Cristal, teachers can carry out orientation and guidance from program schedules, syllabi, curriculum as a guide where teaching focuses on planning jointly initiated by the teacher council and the school principal. The school principal has the duties and responsibilities of leading teachers, students, that planning learning programs, class management as the school principal also monitors professional competence, which is the ability to master material broadly and deeply which allows guiding students to meet national education standards.

The leadership of the school principal provides excellent service to all students so that they can develop their potential to face a future full of challenges. Kusumaningrum (2020) said that there is a significant influence of learning leadership, change leadership, spiritual leadership, school culture, and professional ethics on teacher teaching performance, becoming a resource person for staff, creating a culture and school climate that is conducive to learning, so that the teaching and learning process can go well. Sobri (2018) mentioned about strengthening the Competence of School Principals in Improving the Quality of Education, the school principal should play an optimal role in learning leadership, various programs and activities that can be carried out to encourage teachers to improve academic qualifications according to their field of study, Carrying out a review of learning tools that include the syllabus and (Lesson Plan) periodically, Carrying out supervision, especially in the learning process. Yusup (2015) showed the results of this study indicate that to become an effective school principal as a learning leader, the school principal should not involve in the class.

\section{The Discussion of Product Components in School Principal Leadership at Ensino Secundario Geral Cristal Dili, Timor-Leste}

The results of the evaluation in the Product component are evaluations carried out to measure the success and impact of the school principal leadership program at Ensino Secundario Geral Cristal. The result of the leadership program is the success of human resources who annually graduate highachieving students. Puspitaningtyas (2020) said that the school principal's effort in improving teacher learning is to focus on the needs of students and the effectiveness of the school principal's functions as leaders, supervisors, and managers in schools. The principal as an education leader must identify the needs of teachers, education personnel, and students so that they can learn well (Nurabadi et al., 2021). Sodikin (2017) added that the school principal has made great efforts to improve the competence of teachers and teachers also appreciate it well. School Principal leadership program at Ensino Secundario Geral Cristal showed that every year, graduate students from the school have taken important positions in the Timor-Leste government, many of them attend the State University of Timor-Leste and many of them also continue their studies abroad, this shows the success of these schools that have been achieved. Thus, to find out the results of the product components if Timor-Leste has a national accreditation body to measure the level of success.

\section{CONCLUSION}

Based on the descriptions and analysis of the research results that have been previously stated, it could be concluded that the role of leadership at Ensino Secundario Geral Cristal, Timor-Leste in improving the quality of education has been optimal even though there is still a discrepancy in Design, Installation, Process, and Products obtained by researchers, that the leadership of the school principal in 
Ensino Secundario Geral Cristal, Timor-Leste has discrepancy or has not yet been maximized, this can be seen from:

1. The formulation of the leadership design does not match the criteria and reality in the field, while the discrepancy found is that there has not been an increase in the capacity of the quality of education from the significant changes seen from the education management planning.

2. The component of the school principal's leadership installation has a program planning that is in accordance with this. It appears that there is still a discrepancy in the implementation of the organizing program.

3. Process Components of the implementing planning programs has been in accordance with the curriculum of the Timor-Leste government, namely the Ministry of Education and culture, which is integrated with the curriculum created together with school institutions and the Timor-Leste Cristal Foundation, although it is seen that there is still a discrepancy in the implementation by teachers for the teaching and learning process. everything goes with what has been socialized.

4. In the leadership product component stage at Ensino Secundario Geral Cristal has increased human resources but it still needs to pay attention to the discrepancies that exist in order to improve the quality of education through learning leadership.

5. In the fifth stage of evaluation, it is eliminated because it is a component in the evaluation of the discrepancy model that needs further research for development.

\section{REFERENCES}

Carpente, D. (2015). School culture and leadership of professional learning communities. International Journal of Educational Management, 29(5), 682-694. https://doi.org/10.1108/IJEM-04-2014-0046

Hasibuan. (2018). Manajemen Sumber Daya Manusia. In Manajemen Sumber Daya Manusia.

Konstitusi Republik Demokratik Timor-Leste, Pasal 59 tentang pendidikan dan kebudayaan. (2002). 22.

Kusumaningrum, D. E., Sumarsono, R. B., \& Gunawan, I. (2020). Pengaruh Kepemimpinan Pembelajaran, Kepemimpinan Perubahan, Kepemimpinan Spiritual, Budaya Sekolah, dan Etika Profesi terhadap Kinerja Mengajar Guru. Jurnal Manajemen Dan Supervisi Pendidikan, 4(3), 198-219. https://oi.org/10.17977/ um025v4i32020p198

Maisyaroh, D. F. H. I. B. (2018). Intensitas Komunikasi Kepala Madrasah, Guru, Dan Tenaga Kependidikan Dalam Meningkatkan Mutu Pendidikan Denantia. Jurnal Adminitrasi Dan Manajemen Pendidikan, 1, 150-159.

Nadur, E. S. (2011). Implementasi kepemimpinan transformasional kepala sekolah dalam membentuk budaya sekolah pada konteks pendidikan di indonesia. Jurnal Penelitian., 21(1), 48-61.

Notariado, R. M. J. (RDTL). (2009). No Title. 8116.

Nurabadi, A., Irianto, J., Bafadal, I., Juharyanto, Gunawan, I., \& Adha, M. A. (2021). The Effect of Instructional, Transformational and Spiritual Leadership on Elementary School Teacher's Performance and Student's Achievement. Cakrawala Pendidikan, 40(1), 17-31. https://doi.org/https://doi.org/10.21831/cp.v40i1.35641 puspitaningtyas. (2020). Upaya Kepala Sekolah dalam Meningkatan Pembelajaran Guru di Era Revolusi Industri 4.0. Jurnal Manajemen Dan Supervisi Pendidikan, 4(3), 165-172. https://doi.org/10.17977/um025v4i32020p165

Saputro, D. D. (2018). Implementasi Pendidikan Karakter Di Sekolah Menengah Pertama Negeri 1 Sukoharjo Tahun Pelajaran 2017/2018 Disusun. Program Studi Pendidikan Agama Islam Fakultas Agama Islam Universitas Muhammadiyah Surakarta, (1).

Siregar, L. Y. S. (2017). Full Day School Sebagai Penguatan Pendidikan Karakter (Perspektif Psikologi Pendidikan Islam). Fikrotuna, 5(1). https://doi.org/10.32806/jf.v5i1.2945

Sobri. (2018). Penguatan Kompetensi Kepala Sekolah Dalam Meningkatkan Kualitas Pendidikan.

Sodikin, M. (2017). Evaluasi Terhadap Upaya Kepala Sekolah Untuk Meningkatkan Kompetensi Guru Di Sekolah Dasar Negeri Maduretno Kecamatan Kaliangkri Kabupaten Magelang. E-Jurnal Mitra Pendidikan, 1, 380394.

Staf. (2020). Bagian administrasi. ESGC. https://doi.org/10.21009/jmp.08117 
Sunarto. (2019). Kepemimpinan Kepala Sekolah Dalam Meningkatkan Kinerja Pendidik Dan Pengelolaan Pendidikan Di SDN 2 Kepala Sekolah dalam Satuan. 19(1), 55-67.

Warsilah. (2015). Peran Kepala Sekolah Dalam Pengembangan Budaya Sekolah Di Upt Sd Kecamatan Moyudan Kabupaten Sleman. Jurnal Akuntabilitas Manajemen Pendidikan, 3(1), 97-113.

Yusup, M. (2015). Peran kepala sekolah sebagai pemimpin pembelajaran. Manajer Pendidikan, 9, 95-100. 